\title{
Oppiminen ja elämä hallintaan
}

\begin{abstract}
A ikuiskasvatuksen rajojen epämääräisyys on aina pitanyt sen avoinna uusille ja paikkaansa hakeville kasvatus- ja koulutusmuodoille. Edellisessä numerossa näitä edustivat yrittämisen ja yrittäjyyden edistäjät, tässä erityisesti ohjaustoiminnassa mukana olevat. Kuten Camilla Kovero kirjoituksessaan toteaa, on aikuiskasvatuksen historiassa pyrkimys sivistymiseen ja kulloisenkin historiallisen ihmisideaalin todentamiseen ollut perustava. Pohjoismaisessa perinteessä on kuitenkin myös yksilöllisen sivistymisen yhteys yhteisöllisten ja kansaisten ideaalien todentamiseen ollut tärkeä. Tässä konseptissa “aikuisuus” oli suhteessa sosiaalisen elämän kokonaislaatuun. Itseohjautuvan tai -ohjatun oppijan ideaalin yhteyttä yliyksilöllisiin tai kollektiivisiin ideaaleihin ei ole helppoa nähdä. Sen sijaan formaalin oppimisen, kasvatuksen ja opettajuuden sanaston katoamisesta ovat muutkin kuin "heikoille signaaleille" herkistyneet saattaneet aavistaa, että itseohjautumisen, oman oppimisen ja elämän hallinnan asiantuntijuus on tulossa.
\end{abstract}

A ikuiskasvatuksen tulkinta yksilöllisen oppimisen ja elämän halIlinnan ohjaukseksi on eri puolilla Eurooppaa - ja osana EU:n ja kansallisia ohjelmia - yleistynyt. Historiallisesti eri tarkoituksiin ja omalaatuisiksi kehkeytyneistä sosiaalityön ja -kasvatuksen, ammatinvalinnan ohjauksen, nuorisotyön ja -kasvatuksen, työvoimaneuvonnan, opinto-ohjauksen ja jopa organisaatioiden kehittämistyön muodoista on kehkeytymässä jokin institutionaalisesti ja ammatillisesti vielä täsmentymätön uusi toimintakenttä. Tutorit, mentorit, neuvojat, ohjaajat ja kehittäjät ovat nousseet opettajien ja kouluttajien rinnalle aikuiskasvatuksen määrittelijöiksi ja toimijoiksi. Esimerkiksi Englannissa sosiaali-, nuoriso- ja työvoimaohjaajan habituksella toimivat "personal advisers" ovat tulleet osaksi ammatillisten ja aikuiskoulutusorganisaatioiden henkilöstöä, mistä on aiheutunut hämmennystä ja huolta toimenkuvien, työnjaon ja pohjakoulutuksen muutoksista ja niiden seurauksista.

Ohjaustoiminta näyttää useimmiten kohdistuvan ihmisiin, joilla todetaan ongelmia norminmukaisissa opinnoissa, työ- tai muissa yhteiskunnallisissa toimissa. Ohjauksen eri muodoille on yhteistä se, että normina on yksilöllinen oppimisen ja elämän hallinta, jonka "läksyttämisessä” ohjaaja on asiantuntija. Kun toisaalla opinnoissa, työtehtävissä ja arkipäivän toimissa - niiden sisällön 
asiantuntijat entistä useammin jättävät ihmisen itsensä varaan, kuuluu myös itseohjauksen asiantuntijan vetäytyä "perinteisestä” holhoajan ja huolehtijan asemasta. Ohjaustoiminnan voi nähdä osana yleisempää kasvatuksen korvautumista (kompetenssien) oppimisen hallinnoinnilla, mikä tapahtuu niin järjestelmä-, organisaatio-, kuin ohjaajan ja ohjattavan yksilön tasolla. Oppimisen managereille aikuisuus ja lapsuus eivät eriytä ihmisideaalia: yhtäältä ihminen on varhaislapsuudesta asti potentiaalinen oppimisensa ja elämänsä hallinnoija, toisaalta hän on ulkoa määrittyvissä muutoksissa kroonisesti niin keskenkasvuinen kuin vanhentuva.

$\mathrm{M}^{2}$ aailmassa kaikella on taipumus liittyä kaikkeen. Keskustelu ohjaustoiminnan luonteesta ja tarkoituksista koskee itse asiassa koko aikuiskasvatuksen luonnetta ja tarkoituksia. Millaisia ihmis- ja yhteiskuntakäsityksiä, kasvun ja oppimisen päämääriä olemme ohjaustoiminnan sanastoilla ja malleilla oikeuttamassa? Voisiko niiden kautta kysyä yleisemmin yksilöllisen ja yhteisöllisen toisiaan tuottavuutta ja riippuvuutta tai aikuisen ja lapsen aseman suhteellisuutta ja vuorottelua ihmisen elämänkulussa? Onko (koskaan) oikein kieltäytyä jakamasta kasvun ja oppimisen prosesseja toisten kanssa? Kun sosiaalisen luottamuksen ja turvallisuuden kokemukset eivät kumuloidu yhteiskunnassa tasaisesti, voi niiden tarve olla ensisijaista neuvon tai ohjeen pyytämiseen verrattuna. Tämä liittyy kaikkiin sisällöllisiin opintoihin, työtehtäviin tai arkipäivän toimiin, joissa kasvatus tarkoittaa niitä koskevan osaamisen, tiedon ja kokemuksen jakamista toisten kanssa. Vaikka erityisen kasvatuksellisen ohjaustoiminnan tarve saattaa maailmassa silti lisääntyä, voisiko vetäytyvälle ohjausasiantuntijuudelle löytää vaihtoehtoja, jotka eivät asettaisi kohdettaan itseohjautuvan kuluttajaasiakkaan paikalle? Onhan esimerkiksi eri elämänalueille ulottunut jalkautuva ja hakeva neuvonta- ja valistustoiminta kuulunut Suomessa aikuiskasvatuksen (perustavan idean?) alkuperäisiin toteutustapoihin.

Anja Heikkinen

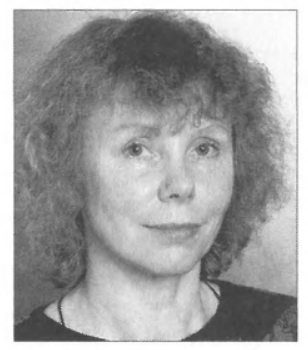

